\title{
Corrigendum: elF3a Regulation of NHEJ Repair Protein Synthesis and Cellular Response to lonizing Radiation
}

\section{OPEN ACCESS}

Edited and reviewed by: Inna N. Lavrik, University Hospital Magdeburg, Germany

*Correspondence: Jian-Ting Zhang

jianting.zhang@utoledo.edu

tThese authors have contributed equally to this work

Specialty section:

This article was submitted to Cell Death and Survival, a section of the journal Frontiers in Cell and Developmental

Biology

Received: 13 November 2020 Accepted: 15 December 2020

Published: 07 January 2021

Citation:

Tumia R, Wang CJ, Dong T, Ma S, Beebe J, Chen J, Dong Z, Liu J-Y and Zhang J-T (2021) Corrigendum: elF3a

Regulation of NHEJ Repair Protein Synthesis and Cellular Response to Ionizing Radiation. Front. Cell Dev. Biol. 8:629218. doi: 10.3389/fcell.2020.629218

\author{
Rima Tumia ${ }^{1 \dagger}$, Chao J. Wang ${ }^{1 \dagger}$, Tianhan Dong ${ }^{1}$, Shijie $\mathrm{Ma}^{2}$, Jenny Beebe ${ }^{1}$, Juan Chen ${ }^{1}$ \\ Zizheng Dong ${ }^{2}$, Jing-Yuan Liu ${ }^{3}$ and Jian-Ting Zhang ${ }^{1,2 *}$ \\ 'Department of Pharmacology and Toxicology, Indiana University School of Medicine, Indianapolis, IN, United States, \\ ${ }^{2}$ Department of Cancer Biology, University of Toledo College of Medicine and Life Sciences, Toledo, OH, United States, \\ ${ }^{3}$ Department of Medicine, University of Toledo College of Medicine and Life Sciences, Toledo, OH, United States
}

Keywords: eukaryotic initiation factor 3a (elF3a), DNA repair, radiation, resistance, mRNA translation, protein synthesis, gamma-H2A histone family member X $(\gamma$-H2AX)

\section{A Corrigendum on}

eIF3a Regulation of NHEJ Repair Protein Synthesis and Cellular Response to Ionizing Radiation

by Tumia, R., Wang, C. J., Dong, T., Ma, S., Beebe, J., Chen, J., et al. (2020). Front. Cell Dev. Biol. 8:753. doi: $10.3389 /$ fcell.2020.00753

In the original article, there was a mistake in Figure $\mathbf{1 A}$ and Figure $\mathbf{3 A}$ as published. Wrong images for the Western blot of H1299 cells in Figure 1A and for the comet assay of the control un-irradiated H1299 cells in Figure 3A were accidently used for publication. The corrected Figures 1 and 3 appear below.

The authors apologize for this error and state that this does not change the scientific conclusions of the article in any way. The original article has been updated.

Copyright (c) 2021 Tumia, Wang, Dong, Ma, Beebe, Chen, Dong, Liu and Zhang. This is an open-access article distributed under the terms of the Creative Commons Attribution License (CC BY). The use, distribution or reproduction in other forums is permitted, provided the original author(s) and the copyright owner(s) are credited and that the original publication in this journal is cited, in accordance with accepted academic practice. No use, distribution or reproduction is permitted which does not comply with these terms. 

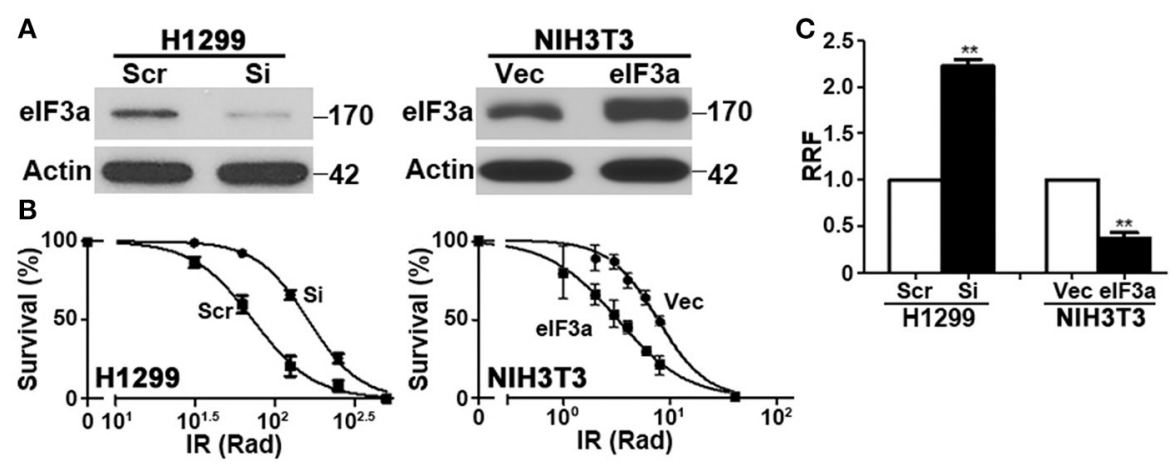

FIGURE 1 | Effect of eukaryotic initiation factor (elF)3a expression on the cellular response to ionizing radiation (IR). Western blot analyses (A) and colony formation assay following IR treatment (B) of $\mathrm{H} 1299$ cells with transient elF3a knockdown and NIH3T3 cells with stable elF3a overexpression compared with their respective control cells. Actin was used as a loading control. Panel (C) shows a summary of elF3a effects on cellular sensitivity to IR treatments. Relative resistance factor (RRF) was derived by dividing the $\mathrm{IC}_{50}$ of the test cells by that of their control cells $\left(n=3,{ }^{\star \star} P<0.01\right)$.
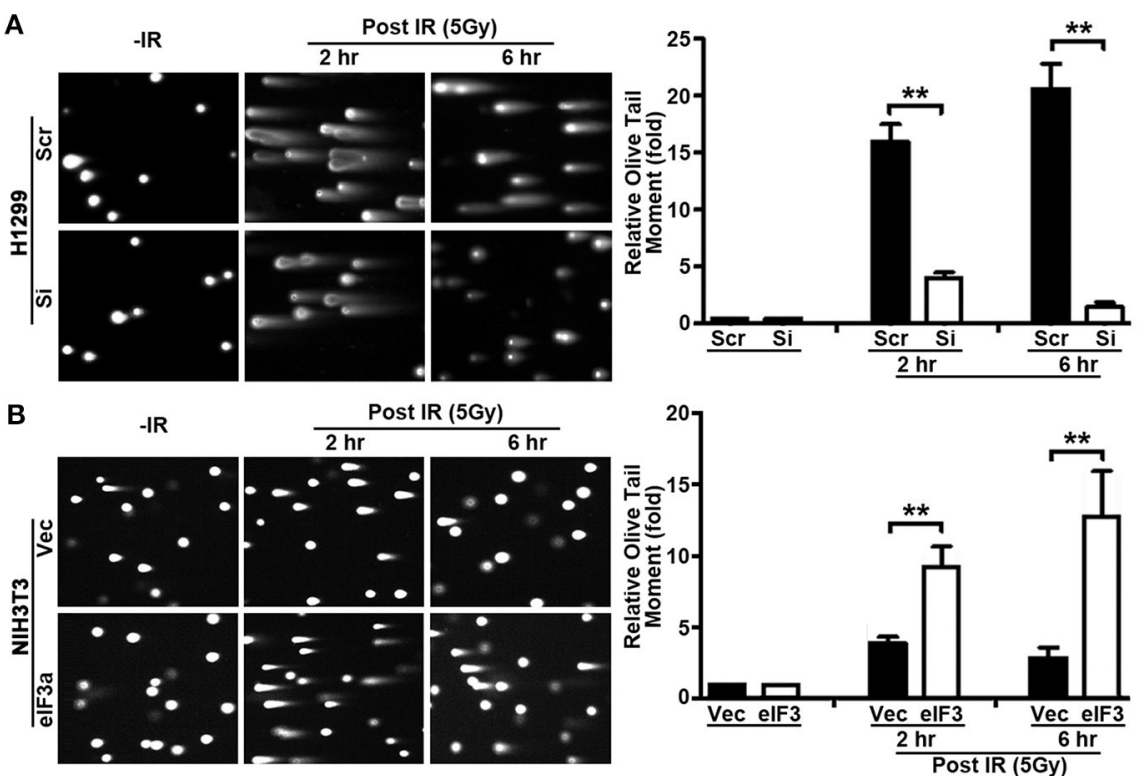
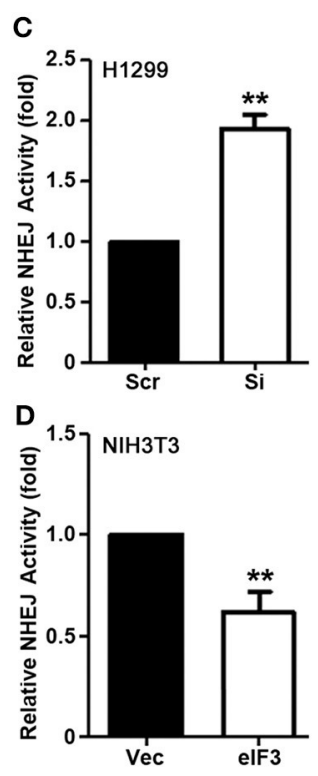

FIGURE 3 | Role of eukaryotic initiation factor (eIF)3a in non-homologous end joining (NHEJ) repair of ionizing radiation (IR)-induced double-strand breaks (DSBs). (A,B) Comet assay was used to determine elF3a effects on the level of DSBs induced by IR in H1299 cells with transient elF3a knockdown (A) and NIH3T3 cells with stable elF3a overexpression (B) compared with their respective control cells. The histograms show the summary of quantitative analysis of Olive tail moment in these cells. (C,D) Host cell reactivation assays using reporter constructs were performed using H1299 cells with elF3a knockdown (C) and NIH3T3 cells with elF3a stable overexpression (D) compared with their respective control cells $\left(n=3\right.$; $\left.{ }^{\star \star} P<0.01\right)$. 